\title{
Worlding with Oysters
}

\author{
Sarah Jane Moore
}

https://orcid.org/0000-0003-3016-8421

Creative Artist \& University of New South Wales, Australia

\begin{abstract}
"Worlding with Oysters" is presented through text, story, song, poetics and image. It explores the opportunities that connecting with nature offers to communities of practice. It asks the collectively conscious to imagine a time oysters spawn in pristine waters and when the smoke of old campfires is remembered as an essential element of the conceptualisation of caring for Sea Country. The poetic essay is hope-filled and hopeful and imagines futures embedded in old ways where rivers and oceans are regarded as essential spaces, rich with metaphor, abundant in story and deep in learning.
\end{abstract}

Keywords: visual arts, story, song, poetry, marine environment, nature, culture, creativity, science, Indigenous knowledge

eTropic: electronic journal of studies in the tropics publishes new research from arts, humanities, social sciences and allied fields on the variety and interrelatedness of nature, culture, and society in the tropics. Published by James Cook University, a leading research institution on critical issues facing the worlds' Tropics. Free open access, Scopus, Google Scholar, DOAJ, Crossref, Ulrich's, SHERPA/RoMEO, Pandora, ISSN 1448-2940. Creative Commons CC BY 4.0. Articles are free to download, save and reproduce. Citation: to cite this article include Author(s), title, eTropic, volume, issue, year, pages and DOI: http://dx.doi.org/10.25120/etropic.19.1.2020.3731 


\section{Worlding with Oysters}

Always was, always will be Aboriginal lands, rivers and sea Countries. [Acknowledgement to Country]

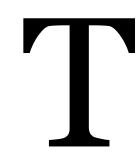

his body of work responds to the old, the ancient and the lived. Through story, song and image, it enables exploration of the ways in which we can secure marine environment futures that are socially, ecologically and spiritually responsive. Written in July 2020, amidst the uncertainties of the global pandemic, these imaginings explore the opportunities and possibilities that worlding with nature and regarding mother earth as our healer offer to communities of practice. It asks the collectively conscious to consider a time when whales come back to safe harbours; when oysters spawn in pristine waters and when the smoke of old campfires is remembered as an essential element of the conceptualisation of caring for Sea Country. Indeed, this process of knowing and becoming intimate and attuned to a lively world is manifested here as worlding (Malone \& Moore 2019).

In ancient times the birds flew free

Ancestral wings did glide

Oysters spawn on milky dawns

And moon bird wings were wide

(from "I know where Oysters lie", a song written and performed by S.J.Moore)

Worlding is the means through which a destabilising of humanist structuring of nature/culture, body/mind divides can be unpacked and interrogated (Malone \& Moore, 2019). Families teach stories to children that affirm and model respect for Country; the importance of spending time caring for and nourishing oceans, rivers, soak holes, waterholes, billabongs and estuaries ripple throughout the interrelated knowingness of Aboriginal Australia. Elders inform communities of their responsibilities to river, sea and estuarine scapes. Through reflective, inclusive practice and the embedding of old ways, populations can interact differently with life's flotsam and imagine futures rich with connection, community and collectivism. The terms upcycling, repurposing or recycling may gain popularity in mainstream dialogues, but here in this expression of oyster worlding, the terms lack currency. Rather, oyster worlding provides a deep and placental pull to the ebb and flow of the earth's tides. 
This creative work is inspired by the stories of science (Niehaus, 2019). It is deeply nourished by observing, reading and understanding the research of Wiradjuri scientist Laura Parker, whose work in climate-proofing the Bandangi (Eora language) or Sydney Rock Oyster (English), stands as testament to a deep passion for saving a species. ${ }^{1}$

When art meets science, stories unfold.

Imaginative selves merge.

Feet take hold.

Under the glass,

Conversations collide.

Beyond the white coats, the oysters lie.

Through gifted shells and echidna quills

Country connects and humans listen;

Oysters sing.

\section{Story}

The ancient oyster shell stories that have been embedded by First Nations peoples around the coasts of Australia and the tropical northern most Torres Strait Islands exist as important cultural spaces and places. Known as middens, they are rich and embodied keeping places for traditional cultural knowledges. Valuing the midden and respecting its contents is an important way for respectful relationships with Sea Country to be conceptualised. As part of middens, oysters become rich, embodied text, to be read, learned and re-learned. Indeed, the midden does not lay the story of waste, but embodies tangible, deep and rich histories and ways of interpreting. A spiritual connection to Healthy Country is fostered, storied and encouraged through family connections, the telling of stories, the harvesting of oceanic foods and the cultivating of a mind-set that connects self, family, sea and community.

"Worlding with oysters" is informed by the social and cultural practices in the harvesting and use of oyster shells enacted by coastal Aboriginal and Torres Strait Islander communities in the lands now known as Australia. First Nations peoples have storied watery worlds since ancestral times and this research dialogue iterates this practice.

\footnotetext{
${ }^{1}$ In Eora/Sydney Aboriginal language see Troy, 2019.
} 
Stories have power and give power. Stories are our law. Stories give identity as they connect us and fulfil our sense of belonging. Stories are grounding, defining, comforting, and embracing. Stories vary in their purpose and content and also stories can be political and yet equally healing. They can be shared verbally, physically or visually. Their meanings and messages teach, admonish, tease, celebrate, entertain, provoke and challenge (Martin, 2008).

This poetic essay written in Tasmania, Australia, on an "island off an island" respects the local palawa Aboriginal language, builds on a long and rich history of research in environmental education that focuses on the value of learning through everyday experiences with the more than human (Malone \& Moore, 2019). It has been nourished by observing children map their respect for minanya (palawa, river), for muka (palawa, ocean), for minanya kitina (rivulet) with stone, shell and play. It is encrusted with memories and created with a deep connection to shell work that is lived and generationally enacted.

Local and Indigenous knowledge refers to the understandings, skills and philosophies developed by societies with long histories of interaction with their natural surroundings (UNESCO, n.d).

With the notion of respectful, culturally safe Indigenous marine governance at its core, this writing embraces local and Indigenous knowledges, understandings and wisdoms. New and old ways (Moore \& Birrell, 2011) are storied, re-storied and embedded in ways of being, knowing and doing (Martin, 2003). The silencing of family stories, the trauma of the Stolen Generations, the disempowerment caused by systemic racism and the removal policies of Aboriginal children from their families have all contributed to the disruption of connectedness and the fragmentation of the cultural threads of caring for Sea Country. Language connection programs, the sharing of stories in communities, the teaching of respecting Country in schools brings strength, power and capacity. The revitalisation of old knowledges brings awareness of shell as a metaphor for cultural practices, a vessel for ancient stories and a safe harbour for unique and valued environmental teachings to find shelter and sustenance.

\section{Song}

"Worlding with oysters" evokes the practices of listening to rivers and of revitalising seascapes by the sharing of old stories and songs. It includes narratives of looking back, looking forward and looking away. Indigenous ways of knowing, being and doing 
(Martin, 2008, 2007, 2003) assist well-being for Aboriginal peoples, and spiritual connections to worlding with birds, fish, whales and other entities ensure that most Aboriginal peoples are raised as environmentalists. The notion of connection is explored through remembering the ancient practices of harvesting sea country, procuring fire, gathering together and sharing food. Remembering the deep learnings that those old campfires bring, those feasts conjure and those ceremonies manifest, brings the power of shells into the now and can inform and breathe life into the respecting of and listening to ocean, water and river. The human breath gives voice to the unheard and the song of the oyster is formed through listening, learning and lamenting. Indeed, a song may ask of the listener, 'who will continue the traditions, to keep the clean rivers flowing, the ocean and river based cultural practices "when I am gone?"' These ideas can be heard in the lyrics and sounds embedded in the song "Look Away". Listen here https://soundcloud.com/user-278409759/look-away.

\section{Poetics}

While most people think of the oyster as a sedentary animal which sits on a rock and does not change; through her microscope, Wiradjuri scientist Laura Parker reveals that during its early life, the Bandangi swim around in the water column and change shape multiple times. Whilst the oysters are becoming, they are fluid, transformative and mobile; they dance! The oyster seeds then select an appropriate spot on which to settle and stay for the rest of their lives. They filter and purify. Ecologically, oysters provide essential ecosystem services including habitat structure for marine organisms, oyster reefs act as a biological filter to purify polluted estuarine water and are a food source for other marine organisms and birds (Gutiérrez et al., 2003; Parker et al., 2013). Economically, oysters form a global industry valued at more than $\$ 1$ billion annually, which employs thousands of people across the globe (FAO, 2014).

The oysters lie in my studio, waiting for stories.

I fill them up; fill them to brimming with questions; with searching, with encounter.

I talk to them.

In whispers.

I talk them.

About them.

Through them.

With them.

I dream them. 
Piled in front of me like glistening Sea Country at times they overwhelm.

Overwhelm me with their volume, their abundance, their noise,

Their need.

I think through them.

With them.

They form in piles on blankets.

I contemplate the inside for I am pearl, I am smooth, I am skin.

Flesh.

I trace the outside with my fingers, my thumbs.

I line them up.

Stack them.

I count them and find ways to connect them, to reconnect them to each other, to themselves and to me.

I try to make them whole.

I wash them; over and over. I turn them.

I turn.

I wash.

I am oyster, I am skin. I am shell; torn and wet.

My hands rub barnacles. I am clinging. Clinging on.

I know where oysters lie.

They lie inside and nourish me, and I filter them.

They fill me with song.

Miss-heard.

Misunderstood.

Missed.

Oysters.

Oyster girl.

Oyster song.

Oyster skin.

I know where oysters lie. 


\section{Image}

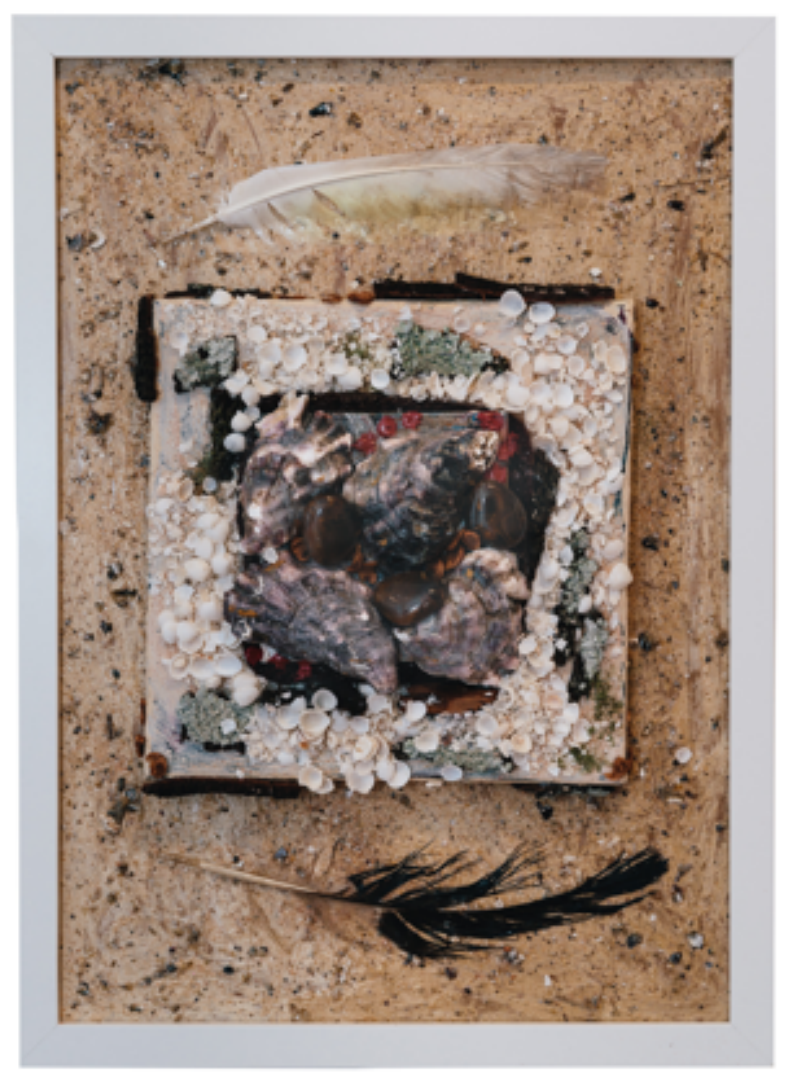

Figure 1. "Rock pools glisten earth tides listen" Sarah Jane Moore, 2019, $35 \mathrm{~cm}$ x $45 \mathrm{~cm}$. Shells, wool, bark, lichen, seeds, clay, cockatoo and gull feathers, stones and ground leaf matter.

Photo: Anton Rehrl of Corvid Photography.

The "Rock pools glisten; earth tides listen" artwork transforms the "waste" of scientific research into visual art practice. Meeting University of New South Wales Indigenous Scientia Fellow and oyster science expert Laura Parker in 2018 and working with her in an intensive six-month residency hosted in the science labs within the School of Biological Earth and Environmental Sciences presented an opportunity for an art meets science approach to be conjured. The residency narrative gave oysters voice, form and visibility through text, song, poetics and visual art.

Parker's research provides solutions to prevent the loss of the Bandangi, while my artwork uses the oysters that Parker seeded, studied and shucked in her experiments with climate proofing Sydney Rock oysters. In discussing the artwork "Rockpools glisten; earth tides listen", a space for story, an opening for text and a place for song 
can be embodied. The artwork features four large oyster shells that are surrounded by tiny white coquina shells. The coquina shells were harvested from Gutharraguda (Shark Bay). The coquinas are a critical part of the coastal ecosystem which keeps Gutharraguda alive. When living, they are well adapted to the high salinity of the waters, when dead, they stabilise the Gatharraguda shoreline. The stories of the shells are framed in flight. A single white cockatoo feather hovers above, and a gull feather drifts below. The feathers story the finely tuned balance of the oyster ecology. "The Rock pools glisten earth tides listen" visual artwork sets up a lifeline; a re-encounter for the viewer to see, connect and know the beauty of sea Country.

\section{Flowing on}

The visual, aural, oral and text-based dialogues presented here are nature-based and worlded in interrelativity, connection and flow. Sharing in narrative-based ways through stories, song, poetry and images has enabled the sharing of river and ocean place-based dialogues to occur. These interdisciplinary conversations celebrate oyster science through visual art practice, poetry and performance. They create, world and sing with oysters so that others may visualise, listen and connect to Sea Country.

Through seashells and sunshine, a new wave begins. 


\section{References}

Malone, K., \& Moore, SJ (2019). Sensing Ecologically through Kin and Stones. The International Journal of Early Childhood Environmental Education, 7(1), 8-18.

Martin, K. L. (2008, April 14). Aboriginal Worldview, knowledge and relatedness theory: a framework for pedagogy and praxis and the teaching - learning interface with Aboriginal students. School of Education, Southern Cross University (Lismore), IATSIS Seminar, Canberra.

Martin, K. L. (2007). The intersection of Aboriginal knowledges, Aboriginal literacies and New Learning Pedagogies for Aboriginal Students. In A. Healy (Ed.), Multiliteracies and diversity in Education (pp. 58-61). Oxford University Press.

Martin, K. L. (2003). Ways of knowing, Ways of being and Ways of doing: A theoretical framework and methods for Indigenous research and Indigenist Research. Journal of Australian Studies, 76, 203-214.

Moore, S. J., \& Birrell, C. (2011). New Ways, Old Ways: Aboriginal Education and Belonging. In N.F. Bagnall \& E.A. Cassity (Eds.), Education and Belonging (pp. 111122). Nova Science Publishers.

FAO. (2014) Yearbook of fishery and aquaculture statistics summary tables. Global aquaculture production. Table A-6. ftp://ftp.fao.org/Fl/STAT/summary/a-6.pdf

Sanga, K. (2017). Leadership development through friendship and storytelling. In U. Vaai \& A. Casamira (Eds.), Relational Hermaneutics: Decolonizing the Mindset and the Pacific Itulagi (pp.101-113). University of the South Pacific Press \& Pacific Theological College.

Troy, J. (2019). The Sydney Language. Aboriginal Studies Press.

UNESCO. (n.d.). What is Local and Indigenous Knowledge? http://www.unesco.org/new/en/natural-sciences/priority-areas/links/relatedinformation/what-is-local-and-indigenous-knowledge/

Niehaus, A. C. (2019). Creating Stories of Science. International Journal of Innovation in Science and Mathematics Education, 27(6), 45-49.

Gutiérrez, J. L., Jones, C.G., Strayer, D.L., \& Iribarne, O.O. (2003). Molluscs as ecosystem engineers: The role of shell production in aquatic habitats. Oikos, 101, 79-90.

Dr Sarah Jane Moore is a creative artist who lives in Tasmania, Australia. She is an Adjunct Associate Lecturer with Biological, Earth and Environmental Sciences (BEES), University of New South Wales, Sydney. In 2019 she was the ANAT On Country resident artist and this opportunity enabled her to develop a deep and listening relationship with the Bandangi (Sydney Rock Oyster). With Wiradjuri Scientist Laura Parker as her muse, she develops interdisciplinary research dialogues that explore an art meets science approach. She is currently an Australia Council funded artist and is working towards an exhibition of stories, songs and visual art that will explore the importance of the oyster to our well-being, environment and waterways. 